\title{
An Analysis of the Path of "Double-line" Mixed Teaching in Ideological and Political Theory Courses in Colleges and Universities
}

\author{
Mengyang Han
}

\author{
China Jiliang University, Hangzhou, 310018, China \\ *Corresponding author.Email: 598046643@qq.com
}

\begin{abstract}
The "double-line" mixed teaching of ideological and political courses in colleges and universities has profound practical value for expanding teaching channels, solving the imbalance of teaching development among schools and accelerating the dissemination and promotion of Marxism. At the present stage, there are some problems in the "double-line" mixed teaching of ideological and political courses in colleges, such as the limited teaching platform, the low enthusiasm of professional teachers in teaching and the low attention of students to course teaching. Therefore, colleges should strengthen the construction of teaching platform, teachers should transform their teaching ideas, and students should strengthen their consciousness of autonomous learning. This paper analyzes the current situation of "double-line" mixed teaching of ideological and political courses in colleges, reveals the difficulties encountered in the teaching process, and probes into the root causes of the problems, strives to break through the teaching "bottleneck", optimize the teaching strategies, and provides reference value for improving the quality of mixed teaching.
\end{abstract}

Keywords: Ideological and political theory courses in colleges, "Double line", Mixed teaching, Path.

\section{INTRODUCTION}

The "double-line" mixed teaching of ideological and political courses in colleges came into being under the background of epidemic prevention and control. It not only effectively compatible with the rational factors of classroom and network, but also improved the teaching efficiency with its systematic and complete teaching links. At present, all universities have restored the order of education and teaching, and the "double-line" mixed teaching mode still plays an important role, so where is its value implication reflected? What development problems are you facing? Can we handle problem effectively and how to optimize the instructional system? It is necessary to dig deep into the current situation of "double-line" mixed teaching in colleges, "sum up the experience of large-scale online education since the outbreak of Covid-19, and use information technology to renovate teaching idea and transform the model of instruction" [1].

\section{THE VALUE IMPLICATION OF THE "DOUBLE-LINE" MIXED TEACHING OF IDEOLOGICAL AND POLITICAL THEORY COURSES IN COLLEGES}

"Double-line" mixed teaching of ideological and political courses in colleges, as the name implies, means that colleges and universities, in the context of conforming to the curriculum teaching reform, create a teaching mode that meets the needs of students' development, organically combine the advantages of classroom teaching and Web-based instruction, enrich the teaching content of ideological and political courses, broaden the teaching approaches in college, and alleviate the contradiction between educational needs and teaching resources. Improve the teaching efficiency, promote the spread of Marxist theory, resist the attack of wrong thoughts. 


\subsection{Conform to the Requirements of the Times and Optimize the Teaching Process}

With the changes of the times, the innovation of the teaching mode is an essential part of the higher education reform. As the most cutting-edge teaching mode, the "double-line" mixed teaching of ideological and political courses fully combines the actual situation of college students, organically unifies classroom teaching, Web-based instruction, theory teaching and practice teaching complements each other's advantages, and systematically plans the teaching process. From the stage of stimulating learning motivation, the "double-line" mixed teaching has narrowed the psychological distance, and effective classroom communication is easier to attract students' attention, prompting students to become curious about theory knowledge and take the initiative to use the network platform to search related teaching resources; From the stage of understanding knowledge, "double-line" mixed teaching pays more attention to the systematization of teaching content, and makes complex theoretical knowledge interesting and live, so that students can have a deep understanding of theoretical principles; From the stage of consolidating knowledge, "Double-line" mixed teaching breaks the time and space limitation of traditional classroom teaching, enlarges the spatial scope of students' learning, and saves a lot of learning time for students to consolidate knowledge; From the stage of applying knowledge, the "double-line" mixed teaching can show practical activities in the form of network video, establish a virtual teaching environment, let students immerse themselves in the experience, and enhance the interest and enthusiasm of theoretical learning; From the stage of checking knowledge, "double-line" mixed teaching can check students' mastery of knowledge anytime and anywhere, and improve teaching efficiency.

\subsection{Effectively Solve the Imbalance of Teaching Development of Ideological and Political Theory Courses among Colleges and Universities}

The application of the "double-line" mixed teaching mode of ideological and political courses in colleges not only promotes the communication between teachers and students, but also strengthens the connection between colleges with the help of the "east wind" of the network platform. From the unbalanced development of domestic universities, the "double-line" mixed teaching has the function of large-scale online learning, which, to a certain degree, "makes up for the uneven the allocation of educational resources and reduces the development gap between universities" [2], so that more educational resources with local characteristics will go to the whole country, benefit teachers and students of colleges , and promote the coordinated development among colleges and universities. From the unbalanced development of international universities, the "double-line" mixed teaching breaks through the geographical boundaries between countries and deepens international exchanges and cooperation with the help of massive data. It can not only learn from the experience of building a mixed teaching model in foreign universities, but also constantly improve and improve the "double-line" mixed teaching model, and promote the teaching reform in domestic universities. It can also promote the ideological and political education teaching mode with Chinese characteristics to the world, improve the reputation of the Chinese teaching mode in the world, let more international friends know about the ideological and political education and Chinese education, and truly realize the sharing of educational resources.

\subsection{Accelerate the Dissemination of Marxist Theory in Ideological field}

Ideological and political courses are the main channels of ideological and moral education and political education in colleges and universities in China, which aims to guide the youthful university students to learn Marxist theoretical knowledge, master the theoretical achievements of Marxism in China, strengthen the socialist stand, and resist the infiltration of western ideology and values. From the perspective of the spread of Marxist theory, the "double-line" mixed teaching combined with classroom teaching and web-based instruction, is aimed at college students of different nationalities, different regions and different majors, "popularizing Marxist theory on a large scale, enabling students to acquire rich scientific knowledge, establishing correct values, distinguishing the attempt of western cultural infiltration, and consciously propagating the scientific and advanced nature of Marxism" [3]. From the perspective of the timeliness of the dissemination of Marxist theory, the "double-line" mixed teaching can help students obtain the latest and most accurate theoretical results of Marxism in China in a short time, enable teachers to quickly modulate the content of courses in combination with important news of current affairs both here and abroad, make colleges become the main positions to actively publicize Marxist theory and enhance the discourse power of Marxism in the ideological sphere.

\section{DISCUSSION ON THE PROBLEM OF "DOUBLE-LINE" MIXED TEACHING OF IDEOLOGICAL AND POLITICAL THEORY COURSES IN COLLEGES}

As a new teaching mode, the "double-line" mixed teaching of ideological and political courses in colleges has a short development time, and it is not deep enough to run in with the current education system in China. It 
has brought many conveniences, but at the same time, a collections of problems have also emerged.

\subsection{The Development of University Platform Technology is Limited, and the "Double-line" Mixed Teaching is Easily Disjointed}

The first problem faced by the application of "double-line" mixed teaching of ideological and political courses in colleges and universities is whether colleges make good use of network technology? Does it guarantee the balanced operation of online and offline platforms? Is the teaching process systematic and reasonable? For the purpose at hand, some colleges pay insufficient attention to online teaching, and still focus on traditional offline classroom teaching, and pay less time and spirit to the construction of "mixed" mixed teaching mode, which makes online teaching work passive. Some colleges are actively responding to the transformation of the teaching mode of ideological and political courses in colleges. However, due to the non-standard network technology, they cannot avoid the risks brought by the "double-line" mixed teaching, and suffer from "insufficient fund investment, unable to take effective practical actions, making all teaching links in a stagnant state" [4]. There are also some colleges and universities that vigorously train teachers, strengthen mixed teaching training, change teaching concepts and actively develop teaching resources, so as to break through the bottleneck of technology and platform construction. However, due to the failure to establish a teaching team that understands both theory and technology simultaneously, in the process of mixed teaching, classroom teaching and Web-based instruction are simply combined, and the teaching content is not reasonably divided, which often leads to problems such as repeated or missing content in teaching, which is extremely detrimental to students' acceptance of knowledge.

\subsection{Teachers' Teaching and Scientific Research Tasks are Heavy and It is Difficult to Mobilize Teaching Enthusiasm}

"Teachers' teaching is an indispensable link in the teaching process, and "double-line" mixed teaching has stricter teaching requirements for ideological and political teachers, which correspondingly increases teachers' workload" [5]. The main task of professional teachers is to guide students into the classroom, learn ideological and political theory knowledge, and meet students' individual needs. In online classroom teaching, teachers need to combine teaching materials to collect plenty of teaching resources and materials, make online courseware, write online teaching logs, master new online teaching methods, strengthen classroom attendance, innovate classroom interaction methods, and guide students to implement on-line studying. In offline teaching, teachers need to break down the barriers of teaching in large classes and small classes, carry out precise education according to the differences of students' development levels, innovate teaching methods, explain profound theoretical knowledge in living language, and attract students to take the initiative to enter classroom teaching.

With the traditional ideological and political teachers gradually changing to the role of "traditional+online" teachers, the amount of teaching tasks is gradually increasing, and the work pressure is also increasing. Some teachers can't adapt to this change of role. They think that "dual-line" mixed teaching challenges teachers' leading position in education, and students' ability to receive network information is stronger, which makes teachers passive in the process of mastering information. Some ideological and political teachers think that "double-line" mixed teaching challenges teachers' authority, and the traditional classroom teaching space is relatively closed, which makes it easier for teachers to establish authority in the process of imparting knowledge. However, in online teaching, the teaching space is no longer limited, which weakens the dependent authority of teachers to master the classroom. All these, the teachers of ideological and political courses have exerted great pressure and worries on the "double-line" mixed teaching mode, and gradually faded their enthusiasm for teaching.

\subsection{Students' Academic Burden is High and Their Attention is Low}

At the stage of entering university, students focus more on the study of professional courses with heavy academic pressure, and do not want to disperse their study energy into the boring study theory knowledge, so they pay less attention to ideological and political courses. In the final analysis, this kind of problem is related to students' learning ability. First, some students have insufficient motivation for autonomous learning. Although the "two-line" mixed teaching mode extends the scope of students' learning and practice space, it still needs to instill students with theoretical knowledge. Students resist learning theoretical knowledge from the bottom of their hearts, and their enthusiasm for learning is not high. Secondly, some students have insufficient self-learning education, and their learning tasks have also increased in the process of "two-line" mixed teaching. Some students are unwilling to make their own learning plans and assign learning tasks according to the requirements of mixed teaching based on passive learning of theoretical knowledge. Third, some autonomous management are lack of ability. Because of the imperfect classroom management system of "double-line" mixed teaching, teachers' management authority is challenged, and students are absent from classroom teaching for no reason, destroying classroom 
discipline and so on, which further indulges the problem of poor management of autonomous learning by college students.

\section{THE OPTIMAL PATH OF "DOUBLE-LINE" MIXED TEACHING OF IDEOLOGICAL AND POLITICAL THEORY COURSES IN COLLEGES}

In view of the problems in the process of "double-line" mixed teaching, both colleges and teachers and students should pay attention to the seriousness of the problem, and jointly improve the "double-line" mixed teaching mode, so that ideological and political courses are closer to the times and life.

\subsection{Colleges and Universities Need to Improve the Construction of Teaching Platform and Promote the Reasonable Connection of Mixed Teaching}

When dealing with the technical platform problem brought by the "double-line" mixed teaching, colleges should first correctly understand the importance of ideological and political education, fit in with the demands of curriculum reform in the new era, encourage active participation in the construction of "double-line" mixed teaching, broaden the ways of classroom teaching, and break the current ideological and political teaching mode rigid status quo. Secondly, colleges should play to the role of top-level design, formulate the teaching development strategy which accords with the actual situation of the school and highlights the characteristics of the construction, rationally allocate teaching resources, and alleviate the unbalanced development of teaching resources of ideological and political courses in colleges. Thirdly, colleges should improve the school infrastructure construction, increase the investment of fund technology, and equip traditional teaching hardware such as projectors and teaching AIDS as much as possible to engage for the reposeful implementation of offline classroom teaching. Finally, colleges should put more punch into the network teaching environment, and cover the wireless network in the campus, so that students can query learning materials online at any place. At the same time, they should promote the staff fusion of artificial intelligence and online teaching, and formulate teaching programs that meet students' cognitive level, so as to make up for the shortcomings of the "double-line" mixed teaching in the network technology level.

\subsection{Teachers Need to Relieve the Pressure of Teaching in Time and Change Their Teaching Concepts}

Teachers of ideological and political courses should transform their educational conceptions, establish equality awareness and "strengthen network awareness" [6], integrate humanistic care into the "double-line" mixed teaching, communicate with students equally through the network, understand and grasp the inner world of students, and gradually guide students to accept and understand those profound theoretical knowledge. Secondly, teachers should also learn to timely change their roles, abandon the outdated "teacher as the main body" thought, re-understand the differences between teachers and students, make good preparation to adapt to the new teaching model, from the traditional classroom control and manager role to the role of guide, organizer, students as the main body of teaching. Thirdly, teachers should consciously strengthen training, master new media technology, impart knowledge to students through online network platforms, learn and draw lessons from teaching modes such as "MOOC", "Flipped Classroom" and "Golden Class", do a good job in classroom teaching design, stimulate students' desire for knowledge and spread their thinking through active classes.. Finally, teachers should innovate teaching methods, change the previous teaching methods based on teaching materials, select teaching resources that can attract students' attention, make teaching videos, supplement with necessary classroom discussions, spread students' learning thinking, enhance students' ability of combining theory with practice, and enhance the charm of ideological and political courses.

\subsection{Students need to Change Their Ideas and Strengthen Their Consciousness of Autonomous Learning}

In the process of accepting the "two-line" mixed teaching, students should first establish a correct learning concept, attach importance to ideological and political courses and professional courses at the same level, pay attention to achievements and understand their own development needs, exchange theory knowledge with classmates and teachers, change individual learning concepts with the driving effect of groups, and actively blend into the "double-line" mixed teaching to enhance self-satisfaction. Secondly, students should improve their autonomous learning ability, actively participate in the process of collecting network information by means of the "mixed" teaching, and cultivate independent learning habits over time to adapt to the learning style under the new teaching mode. Thirdly, students should cultivate self-control consciousness, consciously internalize the teaching content into the heart and externalize it into practice, resist the infringement of bad network information, and 
enhance their learning willpower. Finally, students should play to their subjective role, actively integrate into the ideological and political class, actively explore theoretical knowledge and improve their learning ability.

\section{CONCLUSIONS}

To sum up, the "double-line" mixed teaching of ideological and political courses in colleges and universities, with its advantages of breaking through the boundary of time and space, sharing resources and strong academic quality, is full of strong vitality under the background of ideological and political course teaching reform. However, it is undeniable that the "double-line" mixed teaching is also facing many challenges, which require multi-party cooperation to jointly overcome the current difficulties. Only by constantly exploring and summarizing teaching experience and perfecting the "double-line" mixed teaching in view of the existing problems can we truly promote the development of higher education reform, improve the ideological quality and civilization of young students, enhance the teaching professional level of full-time teachers, and improve the educational ability of colleges.

\section{REFERENCES}

[1] Xi Jinping. Speech at the Symposium of Experts and Representatives in the Field of Education, Culture, Health and Sports [N]. People's Daily, 2020-09-23.

[2] Wang Xinju. Research on Teaching Innovation of Ideological and Political Theory Course in Colleges Based on massive open online course [M]. People's Publishing House, 2019.

[3] Li Guangyan. Research on the Application of Online and Offline Mixed Teaching Mode in Ideological and Political Theory Course [J]. Journal of Jilin Education College, 2020(36).

[4] Li Liu. Discussion on the Mixed Teaching Mode of Ideological and Political Theory Course in Colleges and Universities [J]. Industry and Technology Forum, 2020(19).

[5] Zhao Yao, Wang Jianxin. Value implication, problem research and optimization strategy of "double-line teaching" of ideological and political theory course in colleges and universities in the new era [J]. Ideological Education Research, 2021(01).

[6] Li Lu. Inheritance and Development: Research on Innovation of Ideological and Political Education in Colleges in the New Media Era [M]. Beijing: Beijing University of Technology Press, 2019. 